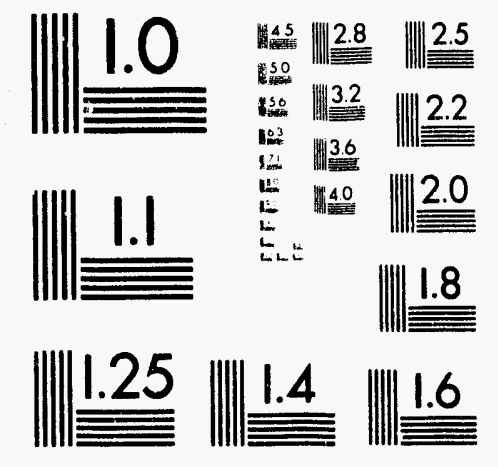



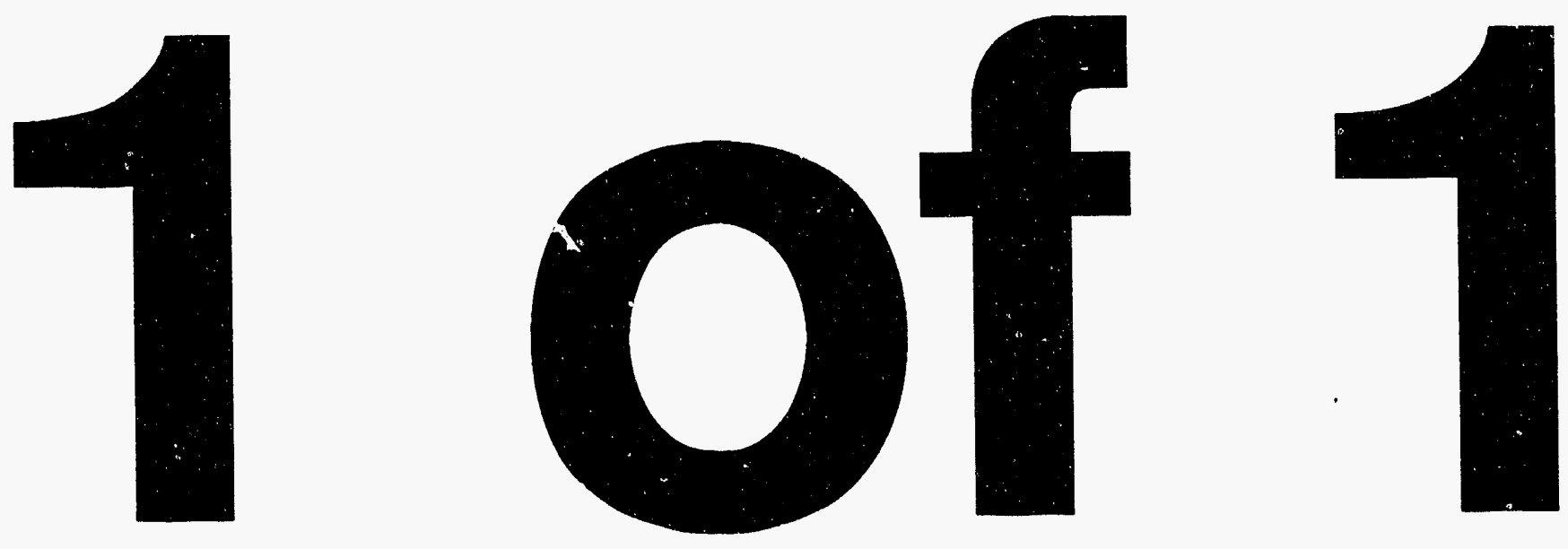


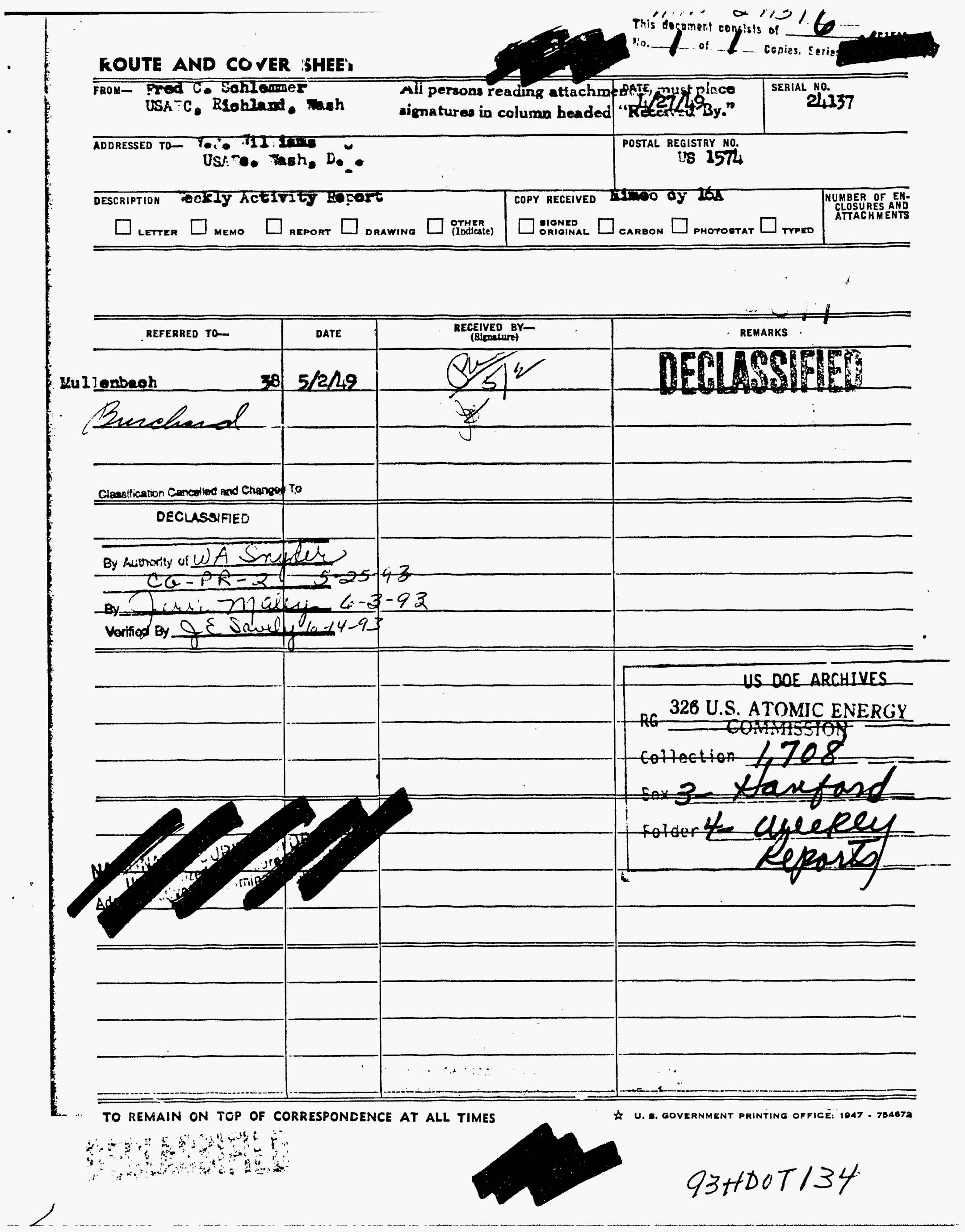


TO: Valter J. VIllliams, USAËC, hashington, D. C.

FRCl: Fred C. Schlemmer, Lanager, Hanford Cperations

Office, Richland, lieshirgton

IVENTS OF TIORTANCE FOR TETI ENDING APRIL 27, 1949

SYLECL: ICH:R R

Enclosed is subject report for week ending April 27, 1949.

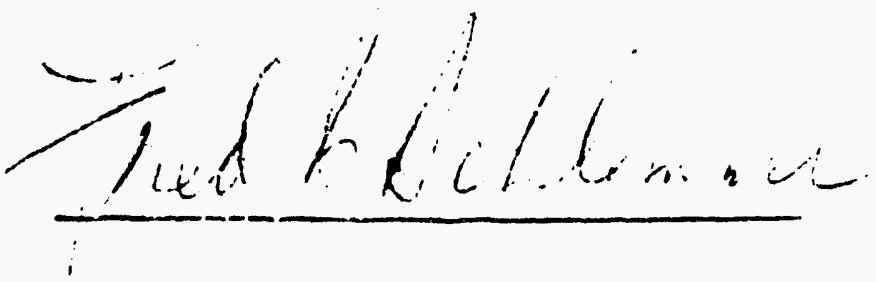

Encl: Copies \#1 thru \#16

\section{DOF ARCHIVES}

\section{DISCLAIMER}

This report was prepared as an account of work sponsored by an agency of the United States Government. Neither the United States Government nor any agency thereof, nor any of their employees, makes any warranty, express or implied, or assumes any legal liability or responsibility for the accuracy, completeness, or usefulness of any information, apparatus, product, or process disclosed, or represents that its use would not infringe privately owned rights. Reference herein to any specific commercial product, process, or service by trade name, trademark, manufacturer, or otherwise does not necessarily constitute or imply its endorsement, recommendation, or favoring by the United States Government or any agency thereof. The views and opinions of authors expressed herein do not necessarily state or reflect those of the United States Government or any agency thereof.

Then separated from enclosures, handle

this document as Ur.classified

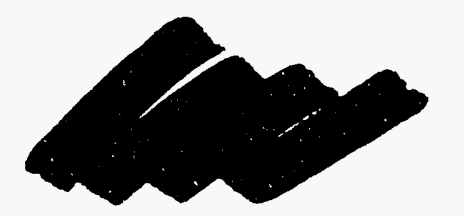

DISTRIBUTION RESTRICTED TO U.S MAT

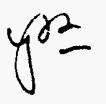




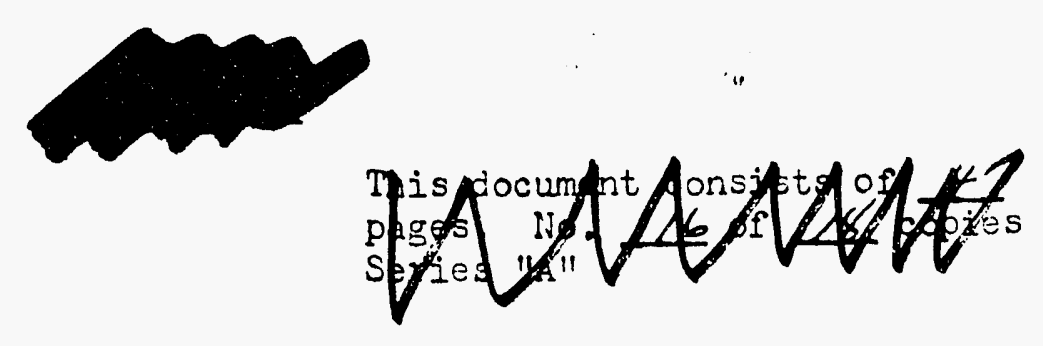

EVEITC CF IIPORTAINCE FOR E EK EINING APRIL 27, 1949

Hanford Operations Offlce

$2: 5: 1$

Richland, Viashington

I - ADMINISTRATICN:

Nc significant events to report.

J. - OPERATICNO:

Net.al Iaste Program:

Tro one-hundred gallon samples of metai. waste were taken from

ine 103-U tank on April 26 for shipner.i to Carbide, Oak Rizge, on Way 4. This concludes the schedulsd sampling program.

\section{Carbon Dioxide:}

The concentration of carbon dioxide in $B$ pile was increased to $40 \%$ on April 22.

Redox:

The five-inch scale-up column was operated for four runs as a If column using the ORNL flow sheet. Tita obtained agrees favorable with that obtained on the A:L flow sheet. Waste losses ranged from .01\% to $.04 \%$ with HETS values of 1.5 feet to 2.1 feet.

\section{Alpha-Rolled lotal:}

Framination of two tons of a lpha-rolied, triple-dipped, conpletely transformed metal exposod to 33.5 inti showed no warping or blistering. Partially transfo-med metal had shown a tendency to warping and blistering.

\section{- 1 - CONSTRUCTION:}

Process Areas:

100 (Pile) Areas:

\section{DOE ARCHIVES}

$100-H$ - liork on the 105-H "B" block assembly is complete, and laminations of the "T" sections are corplete except for "riding of Cell No. 1 on the far side. Instaliation is continuirs on

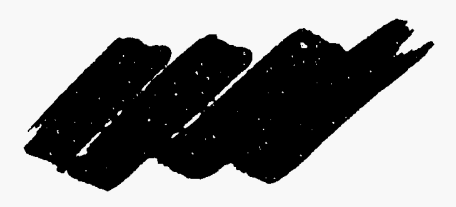

$$
1708-3-4-35
$$




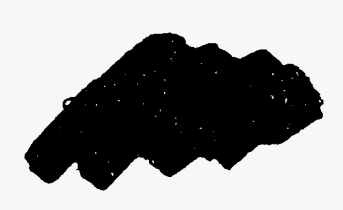

the gunbarrels, donuts, and bellows; horizontal rod guides are being shimmed. The project is now 73\% complete.

$\underline{P-10-A}$ - This project is $20 \%$ complete.

Rala - Specification writing for this project is on schedule.

107.DR - Repair to this retention basin is continuing.

200 (Separation) Areas:

234-5 - Final inspections of Phase I of the 234-5 Building are sineduled for completion by May 6, 1949. This building is $99.3 \%$ complete, and the total project is $98.2 \%$ complete.

Viacte Storage - The 241-BY tank farm is now $69 \%$ complete, and the froject is expected to finish ar:ead of schedule. Two domes have been poured, and re-steel is being set on the thira and fourtia tank domes.

Redox - The DuPont report on Redox has boen received and is being studied.

\section{0 (Netal Fabrication) Area, Ceneral:}

Seventy-five percent ( $75 \%$ ) of the work on the additional services for the 300 Area project has been compieted, and work on various phases of the project is continuing. Irspection of the 3707-C Change House and 24 rooms in the 3706 rjuersion has jeen completed: the job is $95 \%$ complete. The rorkshop (Building 3732) for the 300 Area Plant Assistance Grouf is $7 \%$ complete with framing $=2$ i particring uncerway. A project proposal for increased ventilation of the 313-314 Buildings has been submitted for approval. Total rehabilitation of the 321 Building, which ircludes an increased scope of rork bejond the repair of explosion damage, is now 50,8 complete.

\section{Pich.land Villiage:}

\section{TOE ARCHIVES}

Housing - Exterior painting of the 2,000 "ranch" type homes and the $5 \overline{12}$ conventional type dweilings has bi: $e_{i}$ delayed because of his: winds; the projects are $95 \%$ and $60 \%$ complete, respective $1 \%$. Utility work in the 1,000 house area is nearing completion.

Schools - Operation of the Junior High Schcol cafeteria was commencec April 2l. Stage equipmont in tire Junior Hich is $25 \%$ ins: alleri, and similar equipmeni will be inctalluci in the Spalding shool upon completion of the work in the Jus: or High,

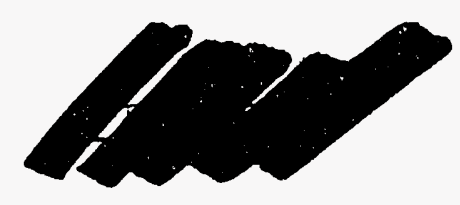


Miscellaneous Construction:

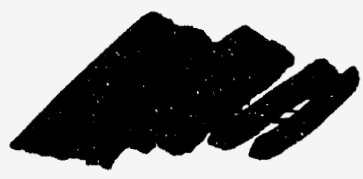

North Storage Reservoir - All work contemplated on this project has been completed.

Street Repair - Patching and seal coating of Village streets are now $50 \%$ complete, with work being delayed pending warmer weather.

Erosion Control - Topsoiling of Village areas has been completed and will be inspected this week prior to seeding. iater line damage hes delayed this work.

Commercial Areas - Sub-grade in the central commercial area has been completed; the two commercial facility buildings are appoximately 85\% complete. Grading, sewers, and water lires are complete in the Swift and Viright Avenue neighborhood shopping area.

Sevare Disposal Plant - This project remail.s at $99.9 \%$ complete. the Dorr representative advises that $\alpha_{2}$ e concrete dome on the jrimary digester will provably Jeak gas and trat sealing of the dome fram the underside may be necessily.

Yakin River Bridge - Pilings are being cin ver in preparation for the Bail.2y Bridge instaliation over the Yakima Fiver on the bypass hifiney system. Complete rehabilization of the brides will be accoiplished by contract with J. A. Terteing rather than by armi forces as had been previously cortemplaied.

$115 \mathrm{KV}$ Transmission Line - This project is :ow $7 \%$ complete,

\section{Personnel:}

There are aporoymately 507 arcintect-mingineer (less Tur:i'uli) and $8, i, r i$ construction employees on the pay roll. Constration camp population is now 7,933 persons, and thers are 502 irailer spaces available for assignment.

\section{$Z^{i}-$ VIFTRES:}

\section{DOE ARCHIVES}

iessrs. Merle Lietzke, Wayne Hanrop, Iao C. Lintner, and liax tyso, of the llalla Walla listrict, Cons of inzineers, visited furil 21 to discuss floor rights and e seme...s in sonnection wil il permanent levees arit removal of cverher. utilities involved.

Mr. E. C. Carlson, Seattie District, Cicros of Engineers, visitec April 27, and discussed emergency flooc protection for Rir.hland during 1949.

Messrs. S. D. Harrington, H. H. Keller, A. B. Butler, from the liellinekrodt Chemical Company, and liessrs. J. E. Viinterlirler, and

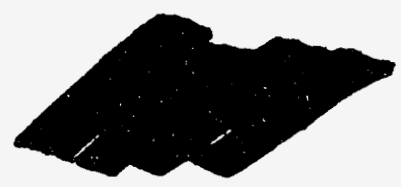




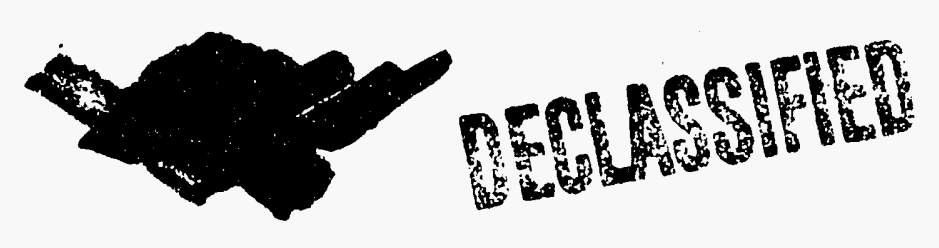

R. Degenhart, from the Electrometallurgical Company, Buffalo, New York, visited April 25-27 to attend a meeting on metal quality.

Dr. H. H. Alexander, of the Sylvania Electric Corp., Long Island, ivew York, visited April 25-27 to discuss new metal fabricating techniques.

Col. H. H. Anderson, It. Col. J. R. Henderson, Lt. Col. Paul T. Rigby, Najor W. E. Kooken, Capt. I. J. Kershort, and liessrs. J. I. Crawford, P. R. Dodge, O'Marsha, I. A. Thomas, from Headquarters, Sixth Army, San Francisco, and Lt. Col. J. E, roods, Fort Bliss, Texas, visited April 21 in connection with difense measures.

DOE ARCHIVES

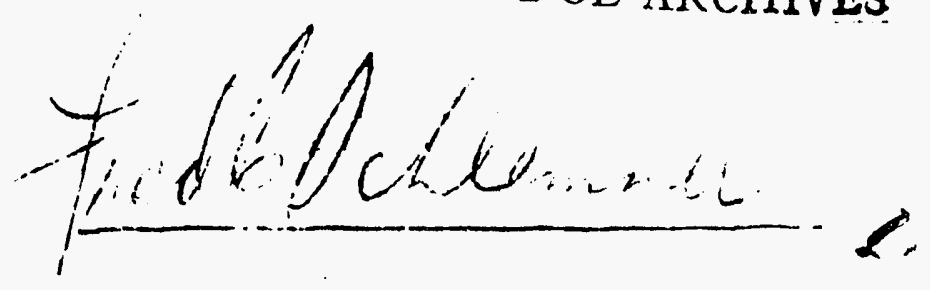



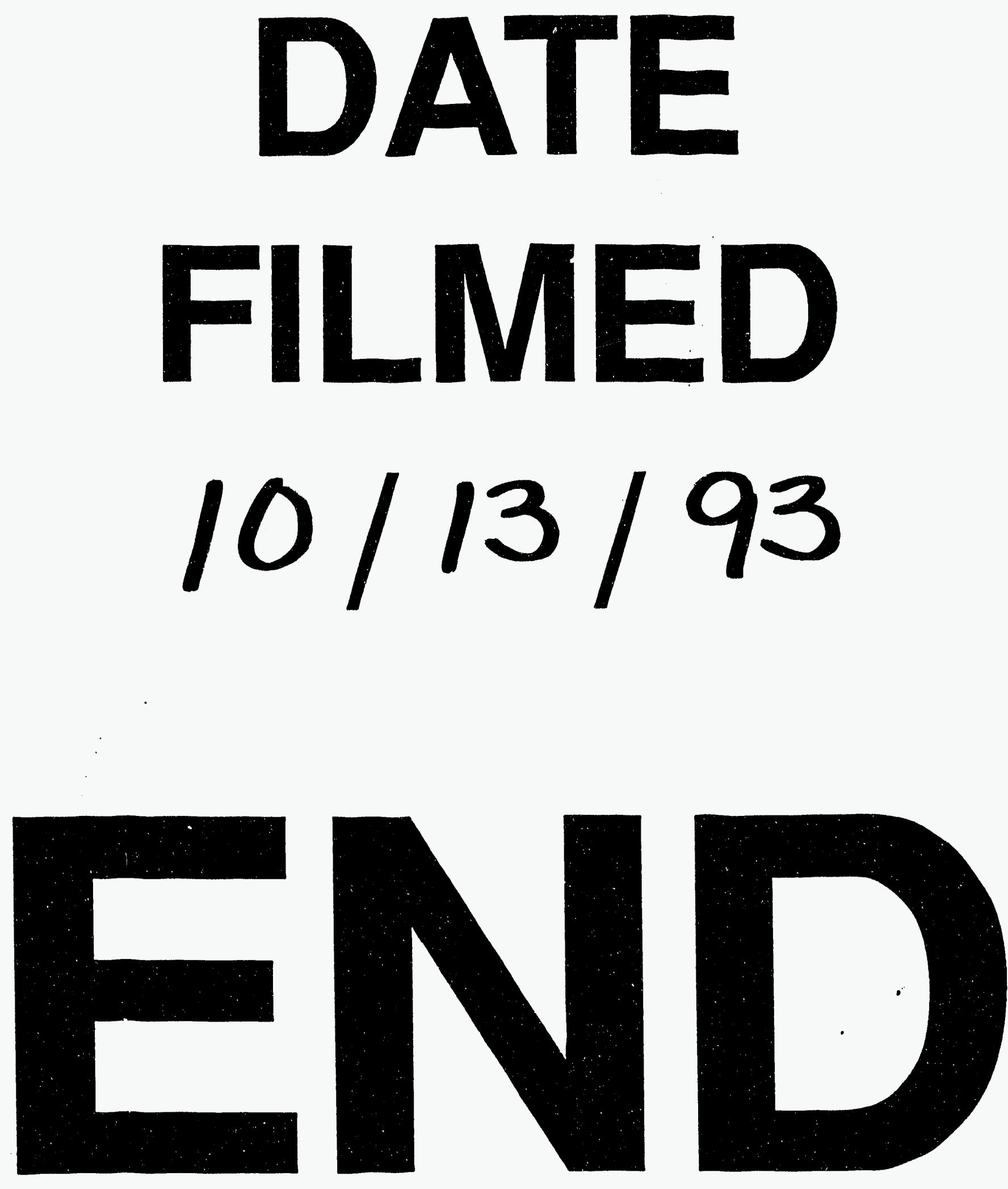
